\title{
NA TRAGU MODERNIZACIJSKIH REFORMI: URBARIJALNE REGULACIJE I ZEMLJIŠNE EVIDENCIJE HRVATSKE I SLAVONIJE DO 1760. GODINE (S OSVRTOM NA JUŽNU UGARSKU)
}

\section{Mirela Slukan Altić}

UDK: 347.235(497.5)“17“

Sažetak: Razdoblje prosvijećene modernizacije obilježeno je brojnim reformama među kojima one koje se odnose na regulaciju zemljišnih odnosa zauzimaju posebno mjesto. U tom smislu karakteristična je pojava državnih urbara čijom će uspostavom pitanja uređenja zemljišnih odnosa i uspostave zemljišnih evidencija prvi puta prijeći iz nadležnosti privatnih osoba (vlastelina) u nadležnost državne centralizirane vlasti. Donošenje Karlovog urbara (1737.) a potom i niza urbarijalnih reformi Marije Terezije kao što su Privremeni urbar za Hrvatsku i Slavoniju (1755.), definitivni Urbar za Slavoniju i Srijem (1756.), Bački urbar (1762.), Ugarski urbar (1767.), Banatski urbar (1780.) te definitivni Urbar za Hrvatsku (1780.), označili su početak novog razdoblja u razvoju kasnofeudalnih odnosa. U sklopu modernizacijskih reformi Marije Terezije izgrađen je posve nov sustav urbarijalnog prava, koji je uz neke dopune, bio na snazi sve do konačnog ukidanja feudalizma 1848. godine. Pojava državnih urbara kao dio širih modernizacijskih reformi, odraz je novog odnosa državnih vlasti prema zemljišnom posjedu i pitanju poreza koje će obilježiti i čitavo razdoblje prosvijećenog apsolutizma.

Ključne riječi: prosvjetiteljstvo, urbar, zemljišne evidencije, 18. stoljeće, Habsburška Monarhija, južna Ugarska

\section{Uvod}

7 emljišne evidencije u mnogim europskim zemljama, osobito onim s jakom imperijalnom tradicijom, imaju dugu povijest te one kao takve nisu izum prosvjetiteljstva. ${ }^{1}$ To

$\square$ vrijedi i za područje hrvatskih zemalja, gdje se već krajem srednjeg i tijekom ranog novog vijeka pojavljuje značajan broj zemljišnih evidencija pojedinih feudalnih ili crkvenih posjeda kao zemljišni dokumenti privatno-pravne naravi. Pojava privatnih zemljišnih evi-

1 Katastar kao sredstvo dokazivanja vlasništva korišten je već u Rimskom Carstvu. O tome usp. Mirela, SLUKAN ALTIĆ, Povijesna kartografija: kartografski izvori u povijesnim znanostima, Zagreb, 2003, 873. U Češkoj prvi pokušaji 
dencija osobito se intenzivira u razdoblju renesanse kada su razvojem kapitalističke ekonomije popisi zemljišta ili planovi zemljišnih posjeda prepoznati kao efikasan instrument privatnog poduzetništva i kontrole prihoda. ${ }^{2} \mathrm{U}$ tom smislu, i u hrvatskom prostoru u to se vrijeme koriste tzv. privatni urbari - zemljišne evidencije pojedinih vlastelinskih posjeda koje su uz temeljnu regulaciju odnosa kmetova i vlastelina mogle utvrđivali i prostornu organizaciju te način korištenja zemljišta u okviru pojedinog vlastelinstva. ${ }^{3}$

Zemljišne evidencije stvarane pod kontrolom državne vlasti te pojava državnih urbara a potom i katastra, karakteristične su upravo za razdoblje prosvijećene modernizacije. Tek tada izrada zemljišnih evidencija prelazi iz privatnih u državne ruke čime one prestaju biti instrument vlastelina te postaju dio javne uprave kojom upravlja državna vlast. Ta je pojava vezana uz porezne reforme odnosno nastojanje vladara da pitanje oporezivanja koje je do tada bilo u rukama lokalnih feudalaca, centraliziranim sustavom stavi pod državnu kontrolu. Porezna reforma bila je preduvjet za uspješnu reorganizaciju vojske koja se regrutirala $s$ feudalnih posjeda te uvelike financirala upravo feudalnim porezima. Tako je uvođenje od države organiziranog poreznog sustava postalo fundamentalno pitanje kroz koje se istovremeno osiguravala kontrola vrlo moćnih lokalnih feudalaca kao i bolje organiziranje vojske odnosno efikasnija obrana Monarhije. ${ }^{4}$

\section{Prvi napori Habsburške Monarhije na uspostavi državnih zemljišnih evidencija - Milanski katastar (1720.-1723.)}

Najstarija državna zemljišna evidencija na tlu Habsburške Monarhije koja je uključivala izmjeru i procjenu zemljišta te zemljišne karte predstavlja tzv. Milanski katastar uveden patentom Karla VI. od 7. rujna 1718. godine (Guinta do Nuovo Censimento Milanese). Kartiranje za potrebe sastavljanja ove zemljišne evidencije proveo je Johann Jakob Marinoni od 1720. do 1723. godine na temelju čega su nastali zemljišni planovi u mjerilu 1:2 000, pregledne karte župa u mjerilu 1:8 000 te pregledna topografska karta u mjerilu 1:72000.5 Svaki plan zemljišta uključivao je oznake granica posjeda i čestica, način korištenja površina, prometne komunikacije, hidrografsku mrežu te naselja. Pri tome je važno naglasiti da je zemljišna evidencija Milanskog katastra obuhvatila sva zemljišta i zemljišne posjede, za razliku od dotadašnjih urbarijalnih zemljišnih evidencija, koje su se odnosile samo na zemljišta pojedinog feudalca. Nažalost, rat za Poljsko naslijeđe od 1733. do 1735. u kojem su francuske i španjolske trupe ušle u Lombardiju, zaustavile su rad na dovršetku Milanskog katastra a do tada sastavljen katastar pohranjen je u utvrdi u Mantovi. Smrt Karla VI. 1740. te Šleski rat (1740.-1748.) još jednom su odgodili dovršetak katastra koji je konačno

uspostave zemljišnih evidencija sežu u 11. stoljeće. Opširnije usp. Jan BUMBA, Česke katastry od 11. do 21. stoleti, Praha, 2007, 12.

Roger KAIN, Elisabeth BAIGENT, The Cadastral Map in the Service of the State, Chicago, 1992, 5-7.

3 Pod privatnim urbarima podrazumijevamo urbare koji se odnose samo na pojedini zemljišni posjed. Najčešće su ih izrađivali pojedini feudalni veleposjednici ili lokalne vlasti. Najstariji sačuvani privatnopravni urbari za područje hrvatskih zemalja potječu iz 15. stoljeća. Više o tome usp. Radoslav LOPAŠIĆ, Urbaria Lingua Croatica Conscripta, Zagreb, 1894

4 Roger KAIN, Elisabeth BAIGENT, The Cadastral Map, 180.

5 Karl LEGO, Geschichte des Österreichischen Grundkatasters. Wien, 1968, 94-96. 
dovršila tek Marija Terezija 1759. godine. Milanski katastar stupio je na snagu 1. siječnja 1760. godine. Osim planova sadržavao je popise zemljišnih i kućnih čestica. ${ }^{6}$

Iako Milanski katastar nije najstariji europski katastar (prethodili su mu švedski katastar iz 17. stoljeća te planovi nizozemskih poldera iz 16. i 17. stoljeća), Milanski katastar svakako je odigrao važnu ulogu u uspostavi katastra kao osnove poreznih reformi u drugim europskim zemljama, a osobito zemljama Habsburške Monarhije. Također, njegova je pojava signifikantna u smislu najave novog odnosa državnih vlasti prema zemljišnom posjedu i pitanju poreza koje će obilježiti čitavo razdoblje prosvijećenog apsolutizma.

\section{Prvi pokušaji urbarijalnih regulacija-između privatnih i državnih urbara}

Prve zemljišne evidencije popraćene pripadajućim kartografskim prikazima na hrvatskom tlu, kao i u većini zemalja srednjoeuropskog kulturnog kruga, nastaju početkom 18. stoljeća. Po svom karakteru te zemljišne evidencije predstavljaju svojevrsni prijelazni oblik između klasičnih privatnih urbara koje smo susretali i ranije te državnih urbara koji se u našim krajevima pojavljuju sredinom 18. stoljeća.

U čemu se te zemljišne evidencije nastale početkom 18. stoljeća razlikuju od klasičnih privatnih urbara? U oba slučaja zemljišne evidencije odnose se na pojedine zemljišne posjede odnosno zemljišta pojedinog vlastelina a ne na ukupno zemljište nekog područja. No, razlika je sada u tome što zemljišne evidencije pojedinih posjeda više ne nastaju isključivo na temelju privatne inicijative, već su dio šire, od strane države potaknute kampanje, inventarizacije zemljišnih posjeda. Za razliku od državnih urbara, u njihovom oblikovanju još uvijek nema strogih pravila a njihova realizacija i kasnije održavanje tako nastalih evidencija prepušteni su lokalnom feudalcu. Njihov nastanak u pravilu je potaknut zemaljskim ili komorskim popisima stanovništva šireg područja te podjelom posjeda. U prostoru hrvatskih zemalja takve se rane zemljišne evidencije pojedinih posjeda pojavljuju uglavnom u Slavoniji gdje je nakon potiskivanja Osmanlija došlo do podijele zemljišta i stvaranja razmjerno prostranih plemićkih posjeda.

Prvi popisi stanovništva i zemljišne procjene u Slavoniji, provedeni su 1698. i 1702. te 1722. godine. ${ }^{7}$ Provođeni po naredbi Dvorske komore, svojim rezultatima, koji su uključivali i popise imovine, predstavljali su svojevrsni sumarni katastar vlastelinstava. ${ }^{8}$ Zanimljivo je da su barem neki od tih sumarnih zemljišnih popisa sadržavali i pregledne kartografske prikaze posjeda s označenim načinom korištenja površina. ${ }^{9}$

\footnotetext{
Isto, 96.
}

Dvorska komora je tijekom prve polovine 18. stoljeća obavila više popisa Slavonije (1702., 1720.-1722., 1736. i 1749.-1750. godine). Popisi su rađeni sa ciljem određivanja visine poreza stanovnicima pojedinoga vlastelinstva odnosno 1749.-1750. godine kako bi vlasnicima posjeda odredila taksu za uvođenje u posjed pojedinoga vlastelinstva. Ive MAŽURAN, „Stanovništvo i vlastelinstva u Slavoniji 1736. godine“, Zavod za znanstveni rad HAZU u Osijeku, Radovi, knj. 6, 1993, 16.

8 Premda su komorski popisivači dobivali upute za obavljanje popisa, oni se nisu u potpunosti pridržavali tih instrukcija pa su spomenuti popisi neujednačeni. Milan VRBANUS, „Skrivena povijest - tajnoviti svijet brojki“, Povijesni prilozi, 39/2010, 39.

9 Jedan od najstarijih svakako je plan posjeda Darda grofa Veteranija iz 1700. godine. Johann i Fridrich Veterani dobili su 1700. godine u posjed 19 sela uz rijeku Dravu na temelju ratnih zasluga njihovog oca. 
Ubrzo, po sličnom obrascu, nastaju i prve detaljne zemljišne evidencije pojedinih posjeda koje su obuhvaćale popise zemljišnih čestica i kmetova kojima su dodijeljene na obradu te prvi puta i kartografski prikaz - urbarijalni plan posjeda. Najstarija takva evidencija do sada pronađena kod nas predstavlja zemljišna evidencija Vukovarskog vlastelinstva iz 1733. godine. ${ }^{10}$ Po njezinom karakteru radi se o privatnom urbaru koji je obuhvaćao niz detaljnih kartografskih prikaza uvezanih u atlas posjeda te pripadajuću knjigu s popisom čestica te iskazima njihovih površina. ${ }^{11}$ Ipak, da se ne radi o klasičnom privatnom urbaru već da je njegov nastanak vezan i za državnu inicijativu, govori činjenica da je sve karte u atlasu izradio ovlašteni kraljevski geometar Johann Philipp Frast (Kaiserlichen Ingenieurs Accademico). Atlas obuhvaća ukupno 25 karata -1 preglednu kartu čitavog vlastelinstva te 24 detaljne karte za svako pojedino naselje s okolnim zemljištem izrađene u mjerilu 1:11 160. ${ }^{12}$ Sve zemljišne čestice prikazane su na razini pojedinih parcela te su označene brojevima.

Slične primjere izrade zemljišnih evidencija posjeda prije uvođenja državnih urbara ili katastra, možemo pronaći i u ostalim dijelovima Habsburške Monarhije. Poznat je atlas vlastelinstva grofa von Hardegga koji je izradio Jakob Marinoni u razdoblju između 1715. i 1727. godine. Isti je autor za Karla VI. izradio i Lovački atlas (Jagdatlas) čije su karte nastale u razdoblju između 1715. i 1727. Godine. ${ }^{13}$ U Ugarskoj je pak poznat atlas veleposjeda Papa (kod Veszpréma) koji je 1735. dovršio János Henrik Maynzeck za grofa Ferenca Esterházyja, koji je također obuhvaćao planove posjeda te popis kmetskih zemljišta. ${ }^{14}$

\section{Odjeci Karlovog urbara iz 1737.}

Prvi pokušaj uspostave urbara od strane centralne državne vlasti predstavlja Slavonski urbar Karla III. (Carolina urbarialis regulatio) koji je donesen 22. svibnja 1737. godine. ${ }^{15}$ Njemu je prethodio popis stanovništva proveden 1736/37. godine koji je kao i prethodni slavonski popisi uključivao i popise zemljišta. Nakon popisa iz 1698. i 1702. bio je to zapravo drugi po redu zemaljski popis stanovništva i njihove imovine koji je obuhvatio čitav prostor slavonskog provincijala od Iloka do Kutine. ${ }^{16}$ Iako zbog velikog otpora feudalnih veleposjednika i rata koji je otpočeo iste godine Karlov urbar u stvarnosti nikada nije stupio na snagu, ${ }^{17}$ taj je urbar zajedno s popisom stanovništva imao stanovite odjeke u sređivanju zemljišnih odnosa i njihovih evidencija. Naime, za potrebe popisa imovine, nastao je stanovit broj zemljišnih (urbarijalnih) popisa i planova posjeda. Do danas pronađen je samo jedan sačuvani plan posjeda (iako teško oštećen) nastao u vrijeme pokušaja uspostave

$\overline{10}$ Zemljišna evidencija Vukovarskog vlastelinstva nastala je nakon što je spomenuti posjed car Karlo VI. 1728. godine darovao grofu Johannu Ferdinandu Küffsteinu, s očitom namjerom popisivanja zemljišta i naselja čitavog vlastelinstva u cilju kontrole ubiranja poreza. Atlas se čuva u Muzeju Slavonije.

11 Gradski muzej Vukovar, Erklaerung der Vuckovaner Mappen.

12 Originalno mjerilo detaljnih karata iznosi 1 Zoll=155 Klafter.

13 Roger KAIN, Elisabeth BAIGENT, The Cadastral Map, 178.

14 Ante GRUBIŠIĆ, Vukovarsko vlastelinstvo na starim kartama iz 1733. godine, Vukovar, 2006, 13.

15 Josip BÖSENDORFER, Agrarni odnosi u Slavoniji, Zagreb, 1950, 71-72.

16 Ive MAŽURAN, Stanovništvo i vlastelinstva, 16.

17 Formalno, Karlov urbar za Slavoniju i Srijem bio je na snazi do 1755., iako se po njemu u praksi nije postupalo. Zemaljska vlast za Slavoniju (Landesstelle für Slavonien) osnovana sa sjedištem u Osijeku, koja je trebala osigurati provođenje urbara, nije uspijevala prisiliti slavonske feudalce da svoje odnose sa kmetovima urede u skladu s urbarom iz 1737. 
Karlovog urbara. Radi se o urbarijalnom planu posjeda Valpovo izrađenom 1736. godine, koji predstavlja svojevrsni zemljišni sumarnik, bez parcelacije zemljišta. ${ }^{18} \mathrm{~S}$ obzirom da je popis Slavonije iz 1736. obuhvatio manje-više sva vlastelinstva, za pretpostaviti je da je u to vrijeme nastao veći broj zemljišnih evidencija i planova vlastelinstava, no pitanje je da li su oni sačuvani. Naime, arhive vlastelinstava zbog čestih promjena vlasnika i ratnih razaranja često su bile teško oštećivane i devastirane, pa je gradivo vlastelinstava koje je do danas sačuvano najčešće parcijalnog karaktera. U tom smislu, za pretpostaviti je da su slični urbarijalni planovi nastali i za područje Đakovačkog, Vukovarskog kao i za neka vlastelinstva zapadne Slavonije te vlastelinstva na području Srijema. Naime, Karlov urbar osim u Slavoniji trebao je vrijediti i za uređivanje feudalnih odnosa na području Srijema.

\section{Državni urbari - Marijaterezijanske zemljišne evidencije kao sustav državne kontrole}

Zemljišne evidencije kao instrument efikasne sustavne državne kontrole na području Habsburške Monarhije pojavljuju se tek uvođenjem prvih državnih urbara. Naime, upravo je neuređenost zemljišnih odnosa koja je omogućavala samovolju lokalnih feudalaca, potakla Mariju Tereziju da u razdoblju između 1747. i 1780. konačno pokrene opsežnije reforme urbarijalnih odnosa na području čitave Monarhije (Theresiana urbarialis regulatio). Bilo je to vrijeme u kojem je Monarhija zbog stalnih ratnih sukoba bila osobito teško opterećena. Ratovanje sa Pruskom koja je 1740. zauzela Šlesku te potom i kratkotrajno Bavarsko zauzimanje Češke, stavili su vladavinu Marije Terezije pred teške izazove. U cilju efikasnijeg punjenja državne blagajne, Marija Terezija 1747. počinje uvoditi poreznu reformu u zemljama austrijske krune i Češkoj. Reforme se isprva nisu odnosile na Ugarsku, pa tako niti na Bačku i Banat. Pod utjecajem fiziokratskih ideja, financijska kriza nastojala se riješiti snažnijim uplivom državne vlasti na nacionalne ekonomije. Na području zemalja austrijske krune u okviru kameralističke doktrine sve veća pažnja posvećuje se problemu pretjerane eksploatacije kmetova (državi je u interesu da seljačko gospodarstvo bude u stanju snositi javne terete) te ujednačavanju urbarijalnih obveza u različitim dijelovima Monarhije. ${ }^{19}$

Sukladno tome, 5. rujna 1747. godine Marija Terezija donosi prvi patent vezan uz regulaciju zemljišnih odnosa, koji je između ostalog obuhvaćao obvezu evidentiranja zemljišnih odnosa na terenu, dakle i izradu kompletnog popisa zemljišta s njihovim kartografskim iskazima. ${ }^{20}$ Već iste godine objavljeno je uputstvo za crtanje karata s kartografskim ključem koji je trebao pridonijeti ujednačenosti svih karata koje će u okviru urbara nastajati u budućnosti. Nadalje, patenti od 9. listopada 1748. i 24. svibnja 1749. zahtijevali su zasebne zemljišne evidencije za kmetsku zemlju (Rustikalfassionen) i za plemićka zemljišta (Dominikalfassionen). Kao nastavak urbarijalnih reformi Marije Terezije već 11. rujna 1755. donesen je privremeni urbar za Slavoniju (tzv. Keglevićev urbar) a 8. studenoga 1755. godine donesen je Privremeni urbar za Hrvatsku. Već 15. ožujka 1756. godine izdan je definitivni

18 Hrvatski državni arhiv, Kartografska zbirka, Grundzeichnung von dem Varosch Valpo/ delineatio S. Freudhoffer.1:14 400.- Valpovo: 1736.- Rukopisna karta: u boji; $94 \times 62 \mathrm{~cm}$.

19 Igor KARAMAN, „Postanak i značenje privremenog urbara za Hrvatsku iz god. 1755“, Radovi Filozofskog fakulteta u Zagrebu, sv. 4/1962, 51

20 Karl LEGO, Geschichte des Österreichischen Grundkatasters, 14. 
Slavonski urbar koji je vrijedio i za Srijem. ${ }^{21}$ Istodobno, počele su se provoditi i zemljišne reforme u južnoj Ugarskoj pa je 1762. donesen Bački urbar kojim su regulirana davanja seljaka na bačkim veleposjedima.

Marijaterezijanski urbari osim što su propisivali urbarijalne odnose feudalaca i kmetova na razini čitave kraljevine, prvi su puta nametnuli i standardizaciju urbarijalnih evidencija. ${ }^{22}$ Tako su već Privremenom urbaru za Hrvatsku iz 1755 . godine priložene standardizirane tabele za popisivanje zemljišta i obveza kmetova. Za razliku od privatnih urbara gdje se urbar sastavljao za feudalni posjed, sada je osnovna jedinica oporezivanja postalo selište pa je svako selo dobilo svoj urbar. Nadalje, provedba urbarijalnih regulacija tražila je osim popisivanja zemljišta i snimanje stanja zemljišta na terenu. Bilo je to prvi puta da na području Hrvatske nastaje čitava serija detaljnih zemljišnih kartografskih prikaza temeljenih na zajedničkim načelima izmjere i kartografskog ključa.

Iako je provedba urbarijalnih regulacija tražila osim popisivanja zemljišta i sustavnu izmjeru zemljišta, zbog nedostatka sredstava kao i velikih otpora plemstva i crkve, sustavna izmjera provedena je odmah samo na području Tirola. U ostalim zemljama Habsburške Monarhije planovi posjeda sastavljani su sporadično. Tako primjerice u razdoblju 1745.1752. nastaje serija zemljišnih planova za posjed St. Florian u Gornjoj Austriji. Također, $\mathrm{u}$ isto vrijeme pojavljuje se i zbirka planova posjeda Weinberga i Wartburga uvezanih u atlas. ${ }^{23}$

Jedan od najljepših primjera marijaterezijanskog urbara koji je i danas sačuvan predstavlja zemljišni plan grada Osijeka nastao 1758/1759. godine koji nastaje odmah nakon donošenja Slavonskog urbara. ${ }^{24}$ Kao i u slučaju planova posjeda s početka 18. stoljeća, i na marijaterezijanskim urbarijalnim planovima najveća pažnja posvećena je prikazu zemljišnih čestica. Ipak, zahvaljujući krupnom mjerilu - 1:7 200, marijaterezijanski planovi posjeda prvi puta prikazuju i strukturu grada na razini pojedinačnih kućnih parcela pa su u tom smislu zanimljiv izvor ne samo za gospodarsku već i urbanu povijest. Osim toga, za grad Osijek već 1747 . počinje se voditi i zemljišna knjiga koji komparativno sa zemljišnim planom daje izvrstan uvid u tadašnje zemljišno-vlasničke podnose. ${ }^{25}$ Ipak, urbarijalne regulacije nisu zaživjele odmah što se može vidjeti $i$ iz uvida u arhivsku građu pojedinih vlastelinstava. Na području Slavonije sačuvano je tek nekoliko zemljišnih evidencija iz razdoblja neposredno nakon donošenja prvog marijaterezijanskog urbara. To potvrđuje i primjer iz Slovenije, gdje je ustanovljeno da u vrijeme reformi Marije Terezije za područje Kranjske nije nastao niti jedan zemljišni plan. ${ }^{26}$ Otpor koji su spomenutim poreznim reformama pružili vladajući slojevi, rezultirali su slabim efektima novog sustava oporezivanja. Nasto-

21 Slavonski urbar sadržava i posebne srijemske regulacije koje su donošene naknadno a odnose se na regulaciju zemljišnih odnosa na posjedima pravoslavnih manastira. Dekretom od 17. lipnja 1774. regulirala je Marija Terezija i selišta pravoslavnog svećenstva. Posebna regulacija donesena je za kontribucije prnjavoraca (pronijara) fruškogorskih manastira čije su obveze usklađene sa Slavonskim urbarom tek 1802. Rakovičkom konvencijom (Conventio Rakoviciana). Josip BÖSENDORFER, Agrarni odnosi, 88.

22 Hrvatski državni arhiv, fond Acta Commissionalia, Prot XI/3, str. 1265-1269.

23 Roger KAIN, Elisabeth BAIGENT, The Cadastral Map, 191.

24 Radi se o planovima Gornjeg i Donjeg grada Osijeka: Original plan von dem Cameral Orth Ober Varosh/ Christian Altinger, Osijek, 1758. Rukopis kolorirani; 90x94 cm, Muzej Slavonije, sign. P-1917 te Plan des Cameral orth Essegger unter Varosch in Sclavonien Betreffent.../F. Blumen, Osijek 1759. Rukopis kolorirani; 109x79 cm.

25 Stjepan SRŠAN, Zemljišna knjiga grada Osijeka 1687.-1821, Osijek, 1995, 5.

26 Branko KOROŠEC, Naš prostor v času in projekciji, Ljubljana, 1978, 137. 
janja Marije Terezije da oporezuje kler i plemstvo, samo su djelomično bili uspješni. Zbog slabe efikasnosti odredbi iz 1755., za područje Križevačke županije koja je 1755. pogođena velikom pobunom seljaka donijet je privremeni urbar 1775. godine. Iste godine takav privremeni urbar ustanovljen je i za Zagrebačku i Varaždinsku županiju. ${ }^{27}$

Godine 1767. godine uveden je Ugarski urbar koji će poslužiti kao obrazac za definitivni Hrvatski urbar iz 1780. godine. ${ }^{28}$ Tek uvođenje definitivnog Hrvatskog urbara 1780. odnosno uspostava Banatskog urbara koji je proglašen 17. listopada 1780. označili su definitivni početak efikasnog normiranja zemljišno-pravnih odnosa. Tako od 1775. odnosno od 1780. nalazimo sve značajniji broj evidencija zemljišnih posjeda, ujednačenog sadržaja i kvalitete koji redovito sadrže i urbarijalne zemljišne planove, s parcelacijom čestica i imenima njihovih posjednika. To vrijedi i za područje južne Ugarske čije zemljišne evidencije i urbarijalne planove u većem broju nalazimo tek nakon 1780. godine.

Pod utjecajem prosvjetiteljskih ideja i fiziokratske ekonomije iz zemalja zapadne Europe, Marija Terezija započela je reforme kojima je cilj bio formiranje jake centralizirane države s djelotvornom upravom i sudstvom. Uspostavljanje državnog urbara i provođenje urbarijalnih regulacija koje je uspostavila Marija Terezija, označio je početak novog razdoblja u razvoju kasnofeudalnih odnosa. U sklopu modernizacijskih reformi izgrađen je čitav sustav urbarijalnog prava, koji je uz neke dopune, bio na snazi sve do konačnog ukidanja feudalizma 1848. godine. Urbarijalne regulacije Marije Terezije uvelike su poboljšale položaj kmetova te ih donekle zaštitile od samovolje feudalnih gospodara. Nadalje, uvođenje obveze sastavljanja zemljišnih evidencija temeljem državnog urbara, označilo je konačno prenošenje zemljišno-pravnih poslova iz ruku privatnih osoba (plemstva) u nadležnost centralnih državnih organa, kao dio širih modernizacijskih reformi. Ipak, te će reforme u punom zamahu zaživjeti tek u nadolazećem jozefinskom razdoblju kada će normiranje zemljišno-pravnih na razini čitave Monarhije dobiti one dimenzije i rezultate koje je priželjkivala Marija Terezija. 


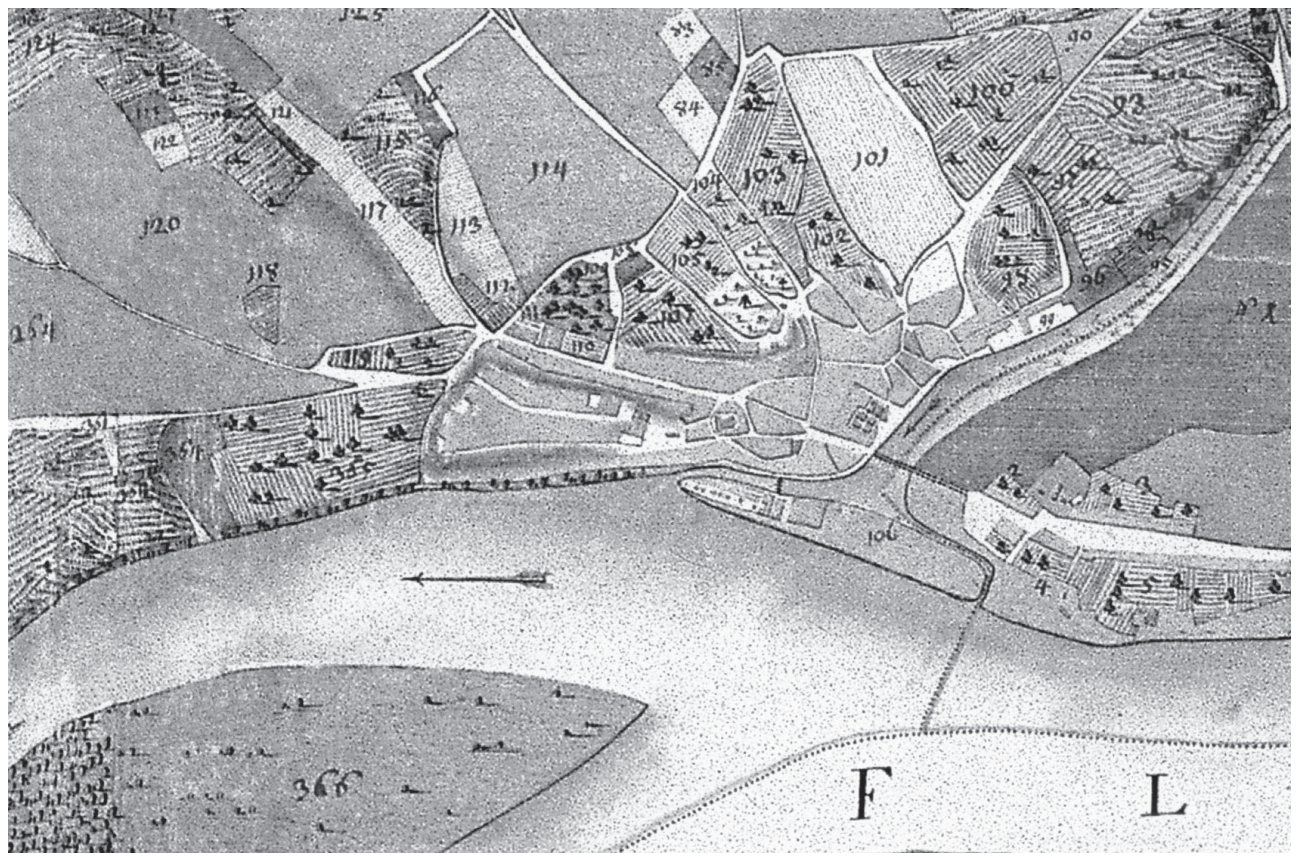

Sl. 1 Vukovar i njegovo vlastelinstvo na urbarijalnom planu iz 1733.

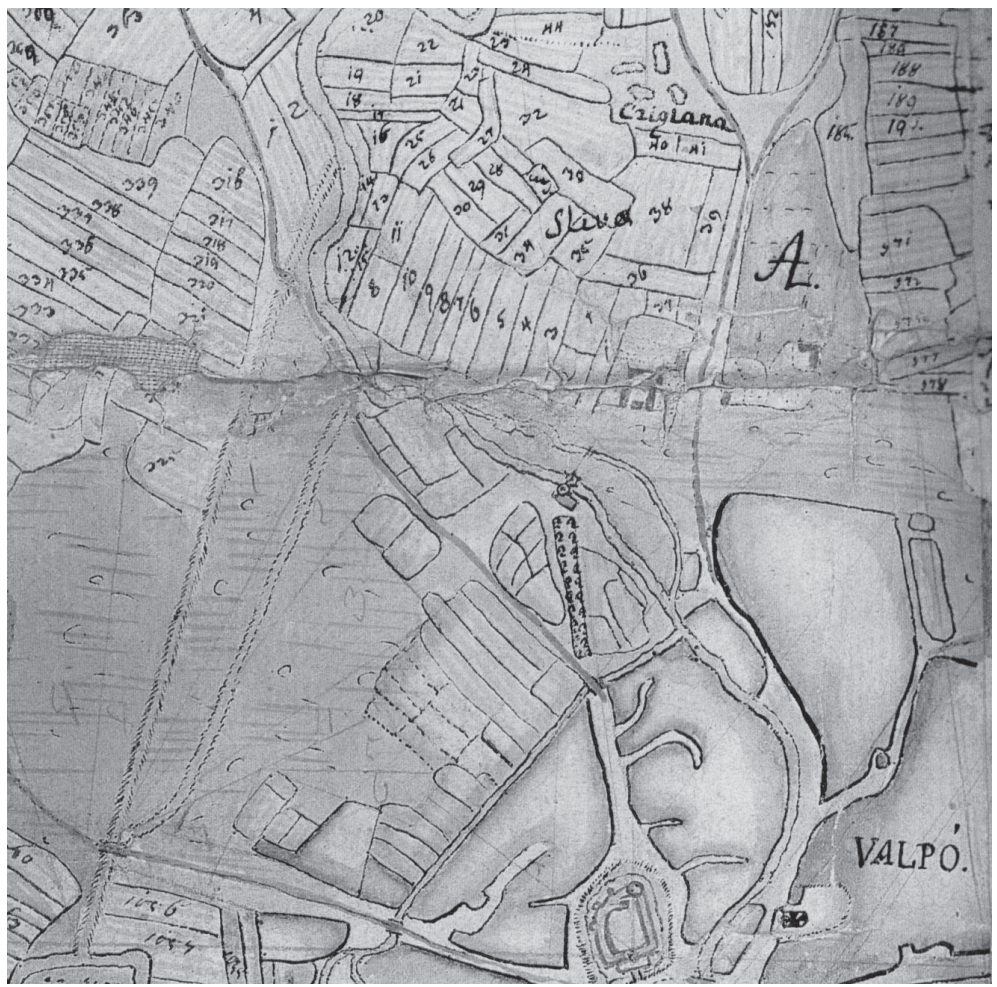

S1. 2 Isječak urbarijalnog plana valpovačkog vlastelinstva iz 1774. godine 


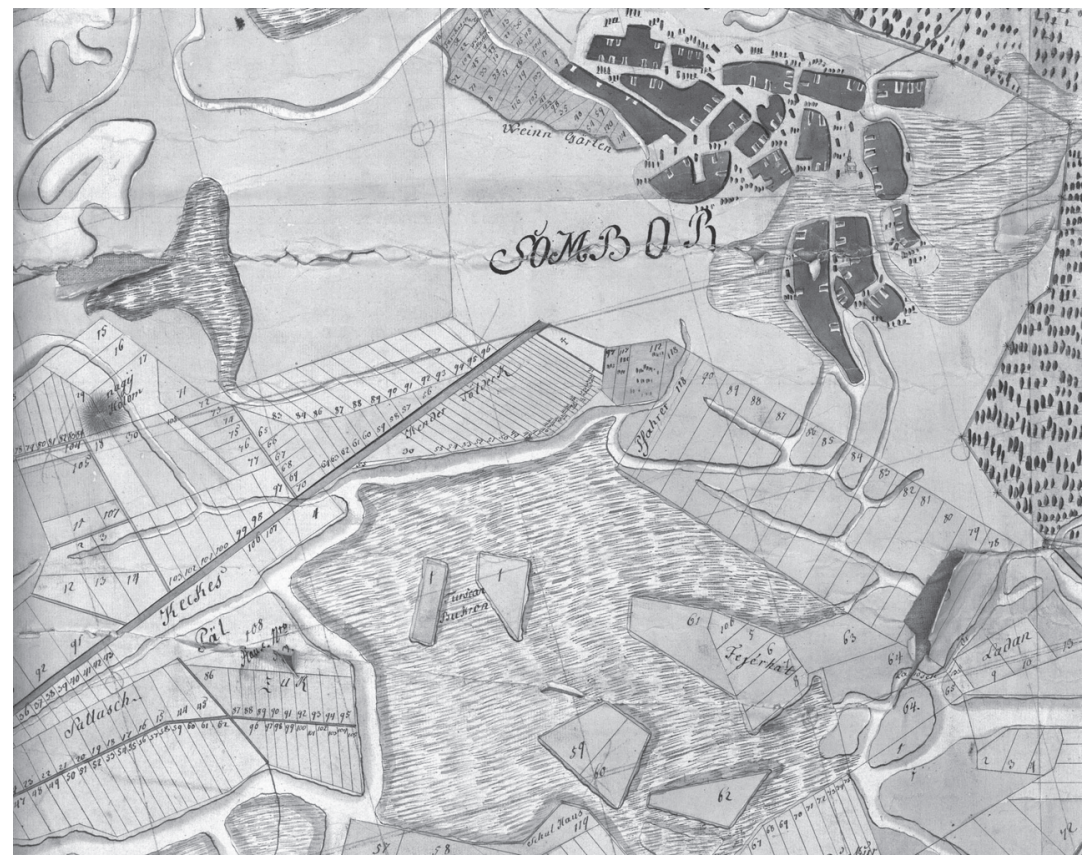

S1. 3 Zemljišni posjedi u okolici Sombora na urbarijalnom planu iz 1783.

\section{On the Track of Modernization Reforms: Urbarial Regulations and Land Records in Croatia AND SlaVonia UnTIL i76o (With Special Reference to Southern Hungaria)}

The period of enlightened modernization was characterized by numerous reforms, among which those relating to the regulation of landed property relations occupy a special place. In this regard one should mention the phenomenon of state urbaria by whose establishment the issues of landed property organization and establishing of land records will for the first time be transferred from the jurisdiction of private individuals (land holders) to the jurisdiction of state-centralized government. The adoption of Charles' Urbarium (1737), followed by a series of urbarial reforms Maria Theresa such as the Temporary Croatian and Slavonian Urbarium (1755), final Slavonian and Syrmian Urbarium (1756), Bačka's Urbarium (1762), Hungarian Urbarium (1767), Banatian Urbarium (1780), and final Croatian Urbarium (1780), marked the start of a new era in the development of late feudal relations. As part of the modernization reforms of Maria Theresa an entirely new system urbarial rights was built. Somewhat amended, this system remained in force until the final abolition of feudalism in 1848. As part of wider modernization reforms, the phenomenon of the state urbaria is a reflection of the new relationship of the state government towards landed property and issue of taxation which will mark the entire period of enlightened absolutism.

Keywords: Enlightenment, Urbarial Regulations. Land Records, 18th century, Habsburg Monarchy, Southern Hungary 


\section{$\cos$}

\section{Popis literature:}

BÖSENDORFER, Josip (1931). „Kako je došlo do slavonskog urbara 1756?“ Rad JAZU, Knj. 240, 220-256; knj. 242, 1-92.

BÖSENDORFER, Josip (1950). Agrarni odnosi u Slavoniji. Jugoslavenska akademija znanosti i umjetnosti, Zagreb.

BUMBA, Jan (2007). Česke katastry od 11. do 21. stoleti. Grada, Praha.

ERCEG, Ivan (1991). „Prilog o uvođenju općehrvatskog urbara 1774“. Acta historico oeconomica Ingoslaviae., vol. 18, 75-89.

GAVRILOVIĆ, Slavko (1958). „Uvođenje urbara u Požeškoj županiji”. Godišnjak Filozofskog fakulteta u Novom Sadu, sv. III, Novi Sad, 55-75.

GAVRILOVIĆ, Slavko (1960). „Urbarijalno pitanje u Sremskoj županiji sredinom XVIII. stoleća”, Zbornik Matice srpske za društvene nauke, 27/1960., 5-32.

GAVRILOVIĆ, Slavko. „Podaci iz 1759. godine o zemljištu i obavezama seljaka Vukovarskog spahiluka“. Spomenica Istorijskog arhiva Srem, 2006, br. 5, 153-164.

GRUBIŠIĆ, Ante (2006). Vukovarsko vlastelinstvo na starim kartama iz 1733. godine. Gradski muzej Vukovar.

HORVAT, Vlado (1991). Zemljišne karte Vukovarskog vlastelinstva kao izvor za povijest istočne Hrvatske poslije oslobođenja od Turaka. Peti znanstveni sabor Slavonije i Baranje, zbornik radova, Osijek, 217-225.

KAIN, Roger; Baigent, Elisabeth (1992). The Cadastral Map in the Service of the State. The University of Chicago Press.

KARAMAN, Igor (1962). „Postanak i značenje privremenog urbara za Hrvatsku iz god. 1755. „Radovi Filozofskog fakulteta u Zagrebu, sv. 4., Zagreb, 51-78.

KARAMAN, Igor (1973). „Sumarni katastar veleposjeda u Slavoniji od 18. do 20. stoljeća“. Radovi Centra JAZUVinkovci.

KOROŠEC, Branko (1978). Naš prostor v času in projekciji. Geodetski zavod Slovenije, Ljubljana.

LEGO, Karl (1968). Geschichte des Österreichischen Grundkatasters. Bundesamt für Eich-und Vermessungswesen, Wien.

LOPAŠIĆ, Radoslav (1894). Urbaria Lingua Croatica Conscripta. Zagreb.

MAŽURAN, Ive (1966). Popis zapadne i srednje Slavonije 1698. i 1702. godine. Građa za historiju Osijeka i Slavonije, knj. 2. Osijek: Historijski arhiv.

MAŽURAN, Ive (1993). Stanovništvo i vlastelinstva u Slavoniji 1736. godine. HAZU, Zavod za znanstveni rad u Osijeku, Radovi, knj. 6.

SLUKAN ALTIĆ, Mirela (2003). Povijesna kartografija: kartografski izvori u povijesnim znanostima. Izdavačka kuća „Meridijani“, Samobor.

SRŠAN, Stjepan (1986). „Pregled gospodarskog i demografskog stanja Vukovarskog vlastelinstva (1728-1736)“. Acta historico oeconomica Iugoslaviae., vol. 13, 189-228.

SRŠAN, Stjepan (1995). Zemljišna knjiga grada Osijeka 1687.-1821. Izdavač Povijesni arhiv Osijek. VEŽIĆ, Milivoj (1882). Urbar hrvatsko-slavonski. Pravničko družtvo u Zagrebu.

VRBANUS, Milan (2010). „Skrivena povijest - tajnoviti svijet brojki“. Povijesni prilozi, vol. 39, $39-71$. 